MaPan : Jurnal Matematika dan Pembelajaran

p-ISSN: 2354-6883 ; e-ISSN: 2581-172X

Volume 8, No 2, Dec 2020 (315-328)

DOI: https://doi.org/10.24252/mapan.2020v8n2a10

\title{
ANALYSIS OF HIGHER ORDER THINKING SKILLS (HOTS) IN MATHEMATICAL PROBLEM SOLVING BASED ON REVISED BLOOMS' TAXONOMY VIEWED FROM GENDER EQUALITY
}

\author{
Ernawati1), Baharullah') \\ 1,2Universitas Muhammadiyah Makassar \\ 1,2Jalan Sultan Alauddin No. 259, Makassar \\ E-mail: ernawati@unismuh.ac.id1), baharullah@unismuh.ac.id2)
}

Received April 28, 2020; Revised May 09, 2020; Accepted December 31, 2020

\begin{abstract}
:
This study aims to determine the description of the results of the analysis of higher order thinking skills in mathematics problem solving based on revised Bloom's taxonomy viewed from gender equality. The subject of the research is two students of SMPN 1 Takalar selected using a purposive sampling technique. The type of research used is descriptive research with a qualitative approach. The description was obtained by analyzing the tests of higher order thinking skills in mathematical problem solving. In this study, instruments in the form of questions test higher order thinking skills based on revised Bloom's taxonomy and the interview guideline. Data collection techniques in the form of test, interview, observation, and documentation. The data analysis technique was data reduction, data presentation, and conclusion drawing/verification. The results of the research show that subjects can use their skills even though still not achieved optimally. Both subjects use almost all aspects of thinking skills based on the revised Bloom's taxonomy, either directly or to bridge the subject in constructing the higher order thinking skills. It shows the difference in students' higher order thinking skills from each category, namely the male and female categories.
\end{abstract}

Keywords: Higher Order Thinking Skills, Revised Bloom's Taxonomy, Problem Solving

\section{ANALISIS KETERAMPILAN BERPIKIR TINGKAT TINGGI DALAM PEMECAHAN MASALAH MATEMATIKA BERDASARKAN REVISI TAKSONOMI BLOOM DITINJAU DARI KESETARAAN GENDER}

\begin{abstract}
Abstrak:
Penelitian ini bertujuan untuk mengetahui deskripsi hasil analisis keterampilan berpikir tingkat tinggi dalam pemecahan masalah matematika berdasarkan revisi taksonomi Bloom ditinjau dari kesetaraan gender. Subjek penelitian adalah 2 siswa SMPN 1 Takalar yang terpilih menggunakan teknik purposive sampling. Jenis penelitian yang digunakan adalah penelitian deskriptif dengan pendekatan kualitatif. Pendeskripsian diperoleh melalui analisis hasil tes keterampilan berpikir tingkat tinggi dalam pemecahan masalah matematika. Instrumen pada penelitian ini berupa soal tes keterampilan berpikir tingkat tinggi berdasarkan revisi taksonomi Bloom
\end{abstract}


serta panduan wawancara. Teknik pengumpulan data berupa tes, wawancara, observasi, dan dokumentasi. Teknik analisis data dilakukan melalui reduksi data, penyajian data, dan verifikasi. Hasil penelitian menunjukkan bahwa kedua subjek dapat menggunakan keterampilannya meskipun tidak tercapai secara maksimal. Kedua subjek melibatkan hampir seluruh aspek keterampilan berpikir berdasarkan revisi taksonomi Bloom, baik secara langsung ataupun untuk menjembatani subjek dalam mengkonstruksi keterampilan berpikir tingkat tinggi. Hal tersebut menunjukkan perbedaan keterampilan berpikir tingkat tinggi siswa dari setiap kategori, yaitu kategori siswa laki-laki dan kategori siswa perempuan.

Kata Kunci: Keterampilan Berpikir Tingkat Tinggi, Revisi Taksonomi Bloom, Pemecahan Masalah

How to Cite: Ernawati \& Baharullah. (2020). Analysis Higher Order Thinking Skills (HOTS) in Mathematical Problem Solving Based on Revised Bloom's Taxonomy Viewed From Gender Equality. MaPan : Jurnal Matematika dan Pembelajaran, 8(2), 315328. https://doi.org/10.24252/mapan.2020v8n2a10.

\section{INTRODUCTION}

7 hinking is to manipulate or manage and transform information into memory (Santrock, 2011). Thinking skills are skills in combining the

Lattitudes, knowledge, and skills to form an effective environment (Anjarsari, 2014). Prowess has the meaning of the ability to do something quickly and correctly. So, the skill of the thought can be defined as the ability to quickly and precisely develop knowledge or ideas by connecting the parts of knowledge resulting in a conclusion that effective.

According to Brookhart (2010), Higher Order Thinking Skills (HOTS) is a student's skills to connect and develop their knowledge during learning to new contexts. The new definition does not have to be universally new, but a form of things that students have not previously thought of. The students' higher order thinking skills are considered learning that can connect the previous knowledge to reach new knowledge.

According to OECD (2014), results of a survey conducted by the Program of International Science Assessment (PISA), which evaluates education systems from 72 countries around the world, shows that the achievement of the ability of students in Indonesia in mathematics competence increased from 375 points in 2012 to 386 points in the year 2015. Indonesia only ranks 64 out of 65 countries with an average score of 375, while the average international score is 500 . This shows that students' ability to solve problems 
that require analysis, evaluation, creation, logic, and reasoning are very less. The ability to think at a high level is defined as using the mind widely to find new challenges (Heong, Othman, Yunos, Kiong, Hassan, Bin, \& Mohamad, 2011). Depdiknas (2006) states that mathematics subjects are given to all learners to equip them to think logically, analytical, systematic, critical, and creative and work together.

Some researchers who research HOTS done by Sulaiman, Muniyan, Madhvan, Hasan, and Rahim (2017) stated that the HOTS test is developed based on Bloom's taxonomy of the cognitive domain, which consists of 20 multiple-choice questions. Based on research conducted by Ariyana, Pudjiastuti, Bestary, and Zamroni (2018) state that (1) the subject that has a high emotional intelligence category shows a good ability to think high level mathematically; (2) the subject that has an average emotional intelligence category shows enough ability to think high level mathematically; (3) the subject that has a low intelligence emotional category shows the low ability to think high level mathematically as well. Research conducted by Saputri, Sugiarti and Murtikusuma (2018) stated that the influence of gender in mathematics because of biological differences in boys' and girls' brains is known through observation. Polya (1973) considers problem solving as the effort to find a way out of a difficulty to achieve a goal that can not be immediately achieved. In line with Fatmawati, Mardiyana, and Triyanto (2014), the existence of a problem encourages students can solve the problem immediately but does not directly solve it. However, the process of solving such problems helps high levels think. So in the years of 1990, Bloom's taxonomy was redesigned by the students of Benjamin Bloom's named Lorin (Anderson \& Krathwohl, 2010). The framework of thinking Benjamin Bloom et al. contain six main categories: knowledge, understanding, application, analysis, synthesis, and evaluation. Then, according to Anderson and Krathwohl, thinking ability learners are grouped in six stages, namely remember, understand, apply, analyze, evaluate, and create. Different from Bloom that uses nouns in the stages of thinking, Anderson and Krathwohl use the verb in the stage of thinking. Reasons for using the theory of Anderson and Krathwohl thinking skills are seen from thinking instead of just looking at the result.

Some of the factors that cause students not to be high-level thinking are the teacher gives questions mathematics for students only up to the level of thinking on the low order. The emphasis on more procedural and mechanistic 
questions does not emphasize understanding. Another factor is in the learning of mathematics teacher gives examples of exercises and exercises is not can develop the ability to think high-level students so that the students are familiar with the questions that the setting of low-level as a result students are not able to analyze, evaluate, and create because it may be one of the most difficult skills to cultivate in the classroom environment. After all, they can think outside the traditional learning steps. Each teacher to overcome the problems in class is different. Each child's characteristics are incorporated in the learning group is very specific, so each teacher also has a strategy for overcoming problems in class.

The importance of analyzing students' thinking skills, especially in high-level thinking skills, is also shown from the demands of the 2013 curriculum, which makes the increase in HOTS (Higher Order Thinking Skills) as one of the learning objectives and assessment. The increase in HOTS is because higher order thinking can push students to think widely and deeply about the subject matter.

Students' analysis skills can be done by exploring their ability to solve problems that represent each indicator of higher order thinking skills based on revised Bloom's taxonomy. Therefore, researchers interested in researching analysis high order thinking skills in mathematical problem solving based on revised Bloom's taxonomy viewed from gender equality to grade VIII students of SMP Negeri 1 Takalar.

\section{METHODS}

The type of this research is included in qualitative research that uses the methodology of descriptive research. This research is described as the students' higher order thinking skills in mathematics problem solving based on revised Bloom's taxonomy. The description is traced through direct observation in completing the problem, namely analyzing the results of the higher order thinking skills test of the students in understanding the problem, plan the completion and evaluation. The data interview also supports the description after the test was conducted.

This research was conducted in SMPN 1 Takalar, Takalar Regency. The research subject was two students of grade VIII. In this study, the research subject is selected based on the ability of the beginning that the students own, the ability to represent the answer, the consideration of teachers of mathematics, and the difference in the categories (of gender equality). 
The instruments used in qualitative research is a test of the higher order thinking skills in the form of a descriptive test. The tests are structured by paying attention to the involvement of each revised Bloom's taxonomy indicator at the level of analyzing (C4), evaluating (C5), and creating (C6). Interview guidelines with the type of semi-structured interview are used to verify the data obtained from the higher-order thinking skills test results.

Table 1. Interview Guidelines

\begin{tabular}{|c|c|c|c|c|}
\hline $\begin{array}{c}\text { Basic } \\
\text { Competence }\end{array}$ & $\begin{array}{l}\text { Competency } \\
\text { Achievement } \\
\text { Indicators }\end{array}$ & Indicators & No & $\begin{array}{c}\text { Level of } \\
\text { Cognitive }\end{array}$ \\
\hline $\begin{array}{l}3.1 \text { Make } \\
\text { generalizatio } \\
\text { ns from } \\
\text { patterns in a } \\
\text { sequence of } \\
\text { numbers and } \\
\text { a sequence } \\
\text { configuration } \\
\text { object }\end{array}$ & $\begin{array}{l}\text { Apply patterns } \\
\text { and } \\
\text { generalizations to } \\
\text { make predictions }\end{array}$ & $\begin{array}{l}\text { Students can } \\
\text { investigate/parse } \\
\text { the information to } \\
\text { take the conclusion } \\
\text { as well as find the } \\
\text { reasons that } \\
\text { support it }\end{array}$ & 1 & C5 \\
\hline $\begin{array}{l}\text { 4.1 Solve } \\
\text { problems } \\
\text { that relate to } \\
\text { a pattern in a } \\
\text { sequence of } \\
\text { numbers and } \\
\text { a sequence } \\
\text { configuration } \\
\text { object }\end{array}$ & $\begin{array}{l}\text { Solve the problem } \\
\text { related to pattern } \\
\text { number, row, } \\
\text { series; use to } \\
\text { solve real } \\
\text { problems }\end{array}$ & $\begin{array}{l}\text { Students can } \\
\text { analyze the tribe } \\
\text { to- } n \text { of a sequence } \\
\text { of numbers and } \\
\text { determine the } S n\end{array}$ & 2 & $\mathrm{C} 4$ \\
\hline $\begin{array}{l}3.1 \text { Make } \\
\text { generalizatio } \\
\text { ns from } \\
\text { patterns in a } \\
\text { sequence of } \\
\text { numbers and } \\
\text { a sequence } \\
\text { configuration } \\
\text { object }\end{array}$ & $\begin{array}{l}\text { Conduct } \\
\text { experiments to } \\
\text { generalize the } \\
\text { patterns of } \\
\text { numbers or } \\
\text { configuration of } \\
\text { the object }\end{array}$ & $\begin{array}{l}\text { Students can } \\
\text { design a method to } \\
\text { solve the problem } \\
\text { and organize the } \\
\text { existing elements } \\
\text { into the structure } \\
\text { of the new that } \\
\text { had not existed } \\
\text { before }\end{array}$ & 3 & C6 \\
\hline
\end{tabular}


Interview questions are arranged only in the form of the course outline, which is based on the stage of the problem solving steps of Polya and develops following the conditions in the field.

In this research, data collection techniques are test methods used to obtain data about students' higher-order thinking skills in solving mathematical problems based on revised Bloom's taxonomy. The interview method was conducted to determine students' higher-order thinking skills and the problem solving phase of the subject based on the step of Polya. Documentation is data collection techniques to search for, collect, and make notes, transcripts, newspapers, magazines, reports, agendas, and others. The presentation of the data would be to use the encoding of the data with the following rules.

SiAXXX

Description:

Si $\quad=$ P subject to the $-\mathrm{i}, \mathrm{i}=1$ and $\mathrm{i}=2$

A $=$ Interpretation of the data

XXX $=$ The order of interpretation of the data begins from 001

In this study, the researcher used triangulation techniques to determine the validity of the data. Sugiyono (2014) stated that the triangulation of time is a test of the data's validity by checking back through the interview, observation, or other techniques in different times or situations. The achievement of time triangulation in this research uses interviews to find the suitability of the data sourced from the same problem at different times. When there is much similarity of the data obtained through triangulation, then the data is declared invalid. Data analysis techniques in this qualitative research consist of several steps proposed by Miles and Huberman (1992), namely data reduction, data display, and conclusion drawing/verification.

\section{RESULTS AND DISCUSSION}

This research was conducted on grade VIII students of SMPN 1 Takalar for 3 weeks. Test of higher-order thinking skills to take data about students' mathematics problem solving ability, whereas the interview is used to determine how the students' process or stages in solving the problem. The instrument used in this research is to test the higher order thinking skills and interview guidelines. All instruments have been through the validation of some of the validators who are experts in their field. 


\section{The Results of the Subject Selection}

The research subject's selection is taken from the 6 students of class VIII.1 of SMPN 1 Takalar in the academic year 2019/2020 who have completed numbers pattern material. Students were given a test of the higher order thinking skills in mathematical problem solving. Classification 2 students of class VIII.1 are divided into two categories: the three students with the man category and three students with the women category.

The test results have been divided, obtained by 2 students who have the highest value, i.e., one male category student and one female category student. The selection of this subject also refers to the ability of the presented answers, communicating well in expressing opinions/ideas orally and in writing is the willingness to follow the overall data collection process in this study.

\section{Description of the HOTS Analysis Results}

The HOTS analysis results of students thinking in solving mathematics problem have been verified through interviews from both subjects summarized in table 2.

Table 2. Description of HOTS Analysis Results (C4)

\begin{tabular}{|c|c|c|}
\hline $\begin{array}{l}\text { Operational } \\
\text { Words C4 that can } \\
\text { Appear }\end{array}$ & S1 & S2 \\
\hline Find & \multirow{5}{*}{$\begin{array}{l}\text { Analyze by way of identifying and } \\
\text { classifying known information that } \\
\text { is used to interpret the problem } \\
\text { into a mathematical model }\end{array}$} & \multirow{5}{*}{$\begin{array}{l}\text { Analyze how to } \\
\text { interpret the } \\
\text { information that is } \\
\text { known to be } \\
\text { linked to the } \\
\text { mathematical } \\
\text { model. However, } \\
\text { the model used } \\
\text { only using the } \\
\text { pattern of } \\
\text { numbers }\end{array}$} \\
\hline Analyze & & \\
\hline Connect & & \\
\hline $\begin{array}{l}\text { Planning The } \\
\text { Completion of the } \\
\text { Study } \\
\text { Find }\end{array}$ & & \\
\hline $\begin{array}{l}\text { Analyze the } \\
\text { Relationship } \\
\text { Groups }\end{array}$ & & \\
\hline
\end{tabular}

\section{The First Subject (S1)}

In solving a problem on the category to analyze the subject involves skills identify, find, carry out plan assessment, and understanding and skills in interpreting, are included in the category of applying. So, based on the revised Bloom's taxonomy, thinking skills categories to analyze (C4) involves skills in understanding (C2) and applying (C3). 


\section{The Second Subject (S2)}

Seen that the results of solving the subject's problem on the category to analyze are right because it was right in using the skills to identify and analyze which belongs to understand the category, so the results of interpretation that belongs to applying the category are correct. Based on the revised Bloom's taxonomy, higher order thinking skills categories to analyze (C4) of the subject category of students who participate in tutoring can analyze well because it can understand (C2) so right in interpreting (C3).

Table 3. Description of HOTS Analysis Results (C5)

\begin{tabular}{|c|c|c|}
\hline $\begin{array}{c}\text { Operational Words C5 } \\
\text { that can Appear }\end{array}$ & S1 & S2 \\
\hline Check & \multirow{7}{*}{$\begin{array}{l}\text { Evaluate by way of } \\
\text { providing an } \\
\text { assessment of a } \\
\text { solution to the } \\
\text { conclusion of solving } \\
\text { the problem, by using } \\
\text { the comparison } \\
\text { Provide arguments } \\
\text { that support what has } \\
\text { been shown by } \\
\text { researchers that using } \\
\text { patterns will be much } \\
\text { easier to work }\end{array}$} & \multirow{7}{*}{$\begin{array}{l}\text { Evaluate by way of } \\
\text { providing an assessment } \\
\text { against a solution to the } \\
\text { conclusion, by comparing } \\
\text { the first with the second } \\
\text { salary } \\
\text { Give arguments about the } \\
\text { use of the mathematical } \\
\text { model with the first } \\
\text { exemplified what is } \\
\text { known in the matter }\end{array}$} \\
\hline States & & \\
\hline Choose & & \\
\hline Gives the Assessment & & \\
\hline Evaluate & & \\
\hline Re-Testing & & \\
\hline Give Arguments & & \\
\hline
\end{tabular}

\section{The First Subject (S1)}

In solving problems in the evaluating categories, a subject involving skills in identifying which are included in the category of understanding, skills in the category of applying, and skills in connecting and comparing that belongs to the category of analyzing. So based on the subject of male students category involves skills in understanding (C2), applying (C3), and analyzing (C4).

\section{The Second Subject (S2)}

Seen that in the solution of problems in evaluating, a subject involves skills in identifying who belongs to the analyze category. So tract revision of Bloom's taxonomy thinking skills categories evaluating (C5) the subject of female students category involves the skills of understanding (C2) and analyzing (C4). 
Table 4. Description of HOTS Analysis Results (C6)

\begin{tabular}{lll}
\hline $\begin{array}{c}\text { Operational Words C6 } \\
\text { that can Appear }\end{array}$ & \multicolumn{1}{c}{ S1 } & \multicolumn{1}{c}{ S2 } \\
\hline Create & $\begin{array}{l}\text { Create by way of } \\
\text { forming a new } \\
\text { structure in the form } \\
\text { of a simple equation } \\
\text { through the ability of } \\
\text { analysis and } \\
\text { application, which is } \\
\text { useful to answer the } \\
\text { problem question; } \\
\text { Create a method to } \\
\text { resolve the problem } \\
\text { by experiment }\end{array}$ & $\begin{array}{l}\text { Designing a method or } \\
\text { find a mathematical } \\
\text { model that is new ever to } \\
\text { resolve the issue with how } \\
\text { to implement the } \\
\text { mathematical model } \\
\text { earlier and solve them } \\
\text { systematically }\end{array}$ \\
\hline to Formulate the & & \\
\hline Outline & & \\
\hline
\end{tabular}

\section{The First Subject (S1)}

In solving the problem in the category of creating, the subject involves skill is exemplified and connect the components of an object included in the category of analysis. Based on the revised Bloom's taxonomy thinking skills category of creating (C6), the male student's category involves analyzing skills (C4).

\section{The Second Subject (S2)}

In solving a problem in the category of creating, the subject involves the skills in remembering (C1) and analyzing (C4).

\section{Discussion}

Based on the students' analytical skill of higher-order thinking in solving the problem of mathematics, the second subject can use his skill even though not achieved optimally. The second subject in the troubleshooting of high level involving almost all aspects of thinking skills based on the revised bloom's taxonomy, either directly or to bridge the subject in constructing the higher order thinking skills.

The analysis results also show differences in students' higher-order thinking skills from each category, namely the category of male students and the category of female students. It can be caused due to the difference between the initial ability of the students. Kawuwung (2011) said that higher-order thinking skills and cognitive learning outcomes are related to beginning students' ability, which are formed through the learning experience of students. 
Based on the description of students' higher-order thinking skills in creating, students' learning experience is very influential in the improvement of the potential possessed by each student. It is caused due to the difference in the learning experience of students. Dimyanti and Mudjiono (2013) states that the learning activity is the establishment of a relationship between the stimulation and response, and the repetition of experiences that have an impact on the number of students in solving mathematical problems that determine the success of the student in better responding to acquire the problem solving that is good and right.

Logically, the participation of the subject in tutoring in mathematics influences how to think high level. This is because the students are familiar with the problems with higher-order thinking so that the achieved development of higher-order thinking skills is optimal, shown from the rightthinking procedure. This is in line with structure and can obtain the right result. Besides, Mulyadi (2010) says that tutoring helps students solve the difficulties associated with learning problems. So the guidance influences the development of students' potential, in this case, the higher order thinking skills in mathematical problem solving.

Higher order thinking skills of both subjects in mathematical problem solving can be identified from each level based on Bloom's taxonomy revision described in the following discussion.

\section{a. The higher order thinking skills of S1 (the First Subject) in mathematics problem solving based on the taxonomy of Anderson}

\section{1) Analyze (C4)}

In the problem solving numbers pattern, the subject can use the skills of analyzing with good and right. The high-order thinking skills of the subject in the analysis are preceded by the skills to identify the information known, then analyze what is being asked in the question, and last interpret each of which is known to connect into a mathematical model.

In solving a problem on the category of analyzing, the subject involving identifying skills, finding, carrying out assessment plan, understanding, and skills in interpreting are included in the category of applying. So, based on the revised Bloom's taxonomy thinking skills categories, the analyze category (C4) involves skills in understanding (C2) and applying (C3).

\section{2) Evaluate (C5)}

In the problem solving pattern numbers, the subject can use the skills to evaluate it appropriately and adequately. When solving the problem, the 
subject of a few times involving the higher order thinking skills in the evaluating, such as in the states, receives and gives the argument information. In the evaluation process, the subject always concludes with the perform identification of each piece of information first and then sees the relationship. Besides that, the subject was also evaluated to conclude in testing the mathematical model.

Seen that in the solution of problems in the categories of evaluating, a subject involving identify skills included in the category of understanding; and skills in groups are included in the category of apply. Communication skills in connecting and comparing belong to the category of analyzing. So based on the subject of male students category involves skills in understanding (C2), apply (C3), and analyzing (C4).

\section{3) Create (C6)}

In the problem solving pattern numbers, the subject can use the skills to create it well and right. At the time of solving the problem, the subject of a few times involving higher-order thinking skills in creating, among which the experiment like never before, involves analyzing, remembering, and understanding. Besides, the subject also designing a strategy by applying some methods, then involve its effectiveness through skill evaluates to find an appropriate solution. In solving a problem in creating, the subject involves skill in the exemplified and connect the components of an object included in the category of analysis. The revised Bloom's taxonomy thinking skills are included in the creating category (C6).

\section{b. The higher order thinking skills of S2 (Subject Two) in mathematical problem solving based on the taxonomy of Anderson:}

\section{1) Analyze (C4)}

In the problem solving pattern numbers, the subject can use the skills to analyze it well but do not use the skills given because forgetting with a mathematical model should be used. The subject began the settlement of the issue by directly interpreting the known information, then plugging in a mathematical model in the form of a pattern. A process precedes the completion of the issue to identify in advance so that the mathematical model obtained is right.

Seen that the results of solving the subject's problem in the analyze category are right because using the skills to identify and analyze which belongs to the category of understanding, so the interpretation results that belongs to the category of applying are correct. Based on the revised Bloom's 
taxonomy, higher order thinking skills categories to analyze (C4) of the subject category of students who participate in tutoring can analyze well because it can understand (C2), so it is interpreted correctly (C3).

\section{2) Evaluate (C5)}

In the problem solving pattern numbers, the subject can use the skills to evaluate it with both at the interview time. When solving the problem, the subject of a few times involving the higher order thinking skills in evaluating, in between that rate and receive information. In the process of the evaluation, subject to conclusions with the identification information in advance.

Seen that in the solution of problems in evaluating, a subject involves identifying who belongs to the analyze category. So tract revision of Bloom's taxonomy thinking skills categories evaluated (C5) the subject of female students category involves the skills of understanding (C2) and analyze (C4).

\section{3) Create (C6)}

The problem solving pattern numbers subject to create by forming a new structure that he had never found before involves analyzing, remembering, and understanding. In solving a problem on the create category, the subject involves the skills remembering (C1) and analyzing (C4).

\section{CONCLUSION}

Thinking skills a high level of students with the category of males in mathematical problem solving based on revised Blooms' taxonomy categories to analyze (C4) involves skills in understanding (C2) and applying (C3). Analyzing the students always involves information that is unknown and in question, then creates a representation of the model the mathematical pattern of numbers. Thinking skills a high level of students with the category of males in mathematical problem solving based on revised Bloom's taxonomy category to evaluate (C5) involves skills in understanding (C2), apply (C3) and analyzing (C4). Evaluating the students involves analyzing it to parse an object to understand its meaning, then decide the truth of the object. Thinking skills a high level of student category of males in mathematical problem solving based on revised Bloom's taxonomy categories create (C6) involves the skill of analyzing (C4) and Evaluate (C5). In creating, students always try something new in decision-making problem solving. Higher order thinking skills of student category of women in problem solving based on revised Bloom's taxonomy categories to analyze (C4) that is able to understand (C2) so that the correct in interpreting (C3). In the analysis on forecast numbers of students to 
directly apply his memory berupad settlement of the issue by forming a pattern of numbers, and then solving the difference between the first pattern with the next pattern. Thinking skills a high level of students with the category of women in problem solving based on revised Bloom's taxonomy category to evaluate (C5) involves skills in understanding (C2) and analyzing (C4). In evaluating, the student can obtain the exact result if shown the correct answer. Thinking skills a high level of students with the category of women in mathematics problem solving based on revised Bloom's Taxonomy categories create (C5) involves skill in remembering (C1), understanding (C2), and analyze (C4). In creating, students always form a new structure to decide the completion of the problem.

\section{REFERENCES}

Anderson, L. W., \& Krathwohl, D. R. (2010). Framework foundation for learning, teaching, and assessment. Yogyakarta: Pustaka Pelajar.

Anjarsari, P. (2014). The Importance of the train thinking skills (thinking skills) in SCIENCE learning. Optimalisasi Implementasi Kurikulum 2013, 1-10. Retrieved from http://staff.uny.ac.id/sites/default/files/pengabdian/ putri-anjarsari-ssi-mpd/pentingnya-melatih-keterampilan-berpikir-criti cal-thinking-dalam-pembelajaran-ipa-smp.pdf.

Ariyana, Y., Pudjiastuti, A., Bestary, R., \& Zamroni. (2018). Handbook skills a high level of thinking based zoning. Direktorat Jendral Guru dan Tenaga Kependidikan dan Kebudayaan.

Brookhart, S. M. (2010). How to Assess Higher Order Thinking Skill in Your Classroom. Virginia USA: Alexandria. Retrieved from http://www.ascd. org/memberbooks.

Depdiknas. (2006). Peraturan menteri pendidikan nasional nomor 22 Tahun 2006 tentang standar konten. 58 mei. Jakarta: Depdiknas.

Dimyanti, \& Mudjiono. (2013). Learning and Learning. Jakarta: Rineka Cipta.

Fatmawati, H., Mardiyana, \& Triyanto. (2014). The analysis of students' critical thinking in solving mathematical problems based on polya on the subject of quadratic equations. Jurnal Elektronik Pembelajaran Matematika, 2(9), 899-910. Retrieved from https://osf.io/preprints/inarxiv/wsza9/.

Heong, Y. M., Othman, W. B., Yunos, J. B. M., Kiong, T. T., Hassan, R. Bin, \& Mohamad, M. M. B. (2011). The level of marzano higher order thinking skills among technical education students. International Journal of Social Science and Humanity, 1(2), 121-125. https:/ / doi.org/10.7763/ijssh.2011. v1.20.

Kawuwung, F. (2011). Profile of teachers, understanding cooperative NHT, and the ability of high level thinking in the junior north minahasa regency. El-Hayah, 1(4), 157-166. https://doi.org/10.18860/elha.v1i4. 
1693.

Miles, M. B., \& Huberman, A. M. (1992). Qualitative data analysis. Beverly Hills, CA: Sage.

Mulyadi. (2010). Diagnosis of learning difficulties and guidance against special learning difficulties. Yogyakarta: NuhaLitera.

OECD. (2014). PISA 2012 results in focus: What 15 years olds know and what they can do with what they know. Paris: OECD Publishing.

Polya, G. (1973). Reviewed work: how to solve it by g. polya. The Mathematical Gazette, 30, 181-182. https:/ / doi.org/10.2307/3609122.

Santrock, J. W. (2011). The development of the child. Jakarta: Erlangga.

Saputri, R. R., Sugiarti, T., Murtikusuma, R. P., Trapsilasiwi, D., \& Yudianto, E. (2018). Analisis kesalahan siswa dalam menyelesaikan soal materi fungsi berdasarkan kriteria watson ditinjau dari perbedaan gender siswa SMP kelas VIII. Kadikma, 9(2), 59-68. Retrieved from https:// jurnal.unej.ac.id/index.php/kadikma/article/view/9710.

Sugiyono. (2014). Metode penelitian pendidikan (pendekatan kuantitatif, kualititatif, dan RED). Bandung: Alfabeta.

Sulaiman, T., Muniyan, V., Madhvan, D., Hasan, R., \& Rahim, S. S. A. (2017). Implementation of higher order thinking skills in teaching of science: a case study in Malaysia. International Research Journal of Education and Sciences, 1(1), 1-3. Retrieved from https://www.masree.info/wpcontent/ uploads/2019/11/Implementation-of-Higher-Order-ThinkingSkills-in-Teaching-of-Science.pdf. 